Miomir Korać

Arheološki institut Beograd

Nemanja Mrđić

Arheološki institut Beograd

Mirko Mikić

Arheološki institut Beograd

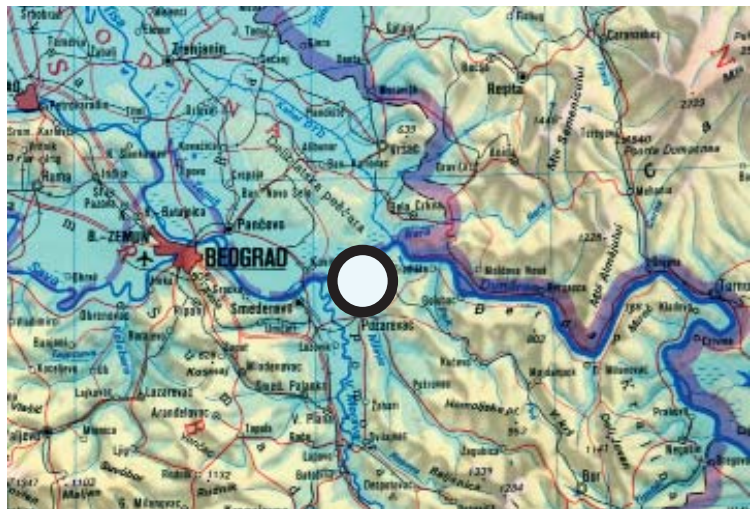

Viminacium, Stari Kostolac, Srbija

LAT 44 44' 09'" / LONG $21^{\circ} 12^{\prime} 42^{\prime \prime}$

\title{
KARTIRANJE RIMSKOG AKVEDUKTA NA VIMINACIJUMU POMOĆU GLOBALNOG SISTEMA ZA POZICIONIRANJE (GPS)
}

\begin{abstract}
ABSTRAKT
U proleće 2003. godine, prilikom radova na površinskom ugljenokopu Drmno, na lokalitetu Stig, bager je presekao zidove za koje se arheološkim i geofizičkim istraživanjima pokazalo da su deo gravitacionog kanala rimskog akvedukta. Zaštitna iskopavanja otkrila su tragove još jednog kanala. Da bi se upoznao sistem vodosnabdevanja i isplanirala buduća zaštitna istraživanja sprovedeno je sistematsko rekognosciranje i kartiranje oba akvedukta. Utvrđena je njihova trasa u dužini od preko $6 \mathrm{~km}$. Korišćena je savremena oprema, a potvrđivanje rezultata rekognosciranja vršeno je na više različitih načina koji uključuju georadarska snimanja, arheološka iskopavanja i praćenje raznih zemljanih radova. Rad prvenstveno ima za cilj da predstavi novi metodološki pristup sistematskom kartiranju arheoloških lokaliteta.
\end{abstract}

KLJUČNE REČI: ViMINACIJUM, KARTIRANJE, AKVEDUKT, GEOFIZIKA, GEORADAR, GPS, GLOBAL POSITIONING SYSTEM, METODOLOGIJA

U proleće 2003. godine, prilikom radova na uklanjanju jalovine, u zoni ispred površinskog ugljenokopa Drmno, na lokalitetu Stig, bager je presekao zidove za koje se arheološkim i geofizičkim istraživanjima pokazalo da su deo gravitacionog kanala rimskog akvedukta (sl. 1). Prve sonde otvorene su u neposrednoj blizini ivice površinskog kopa, na oko 3200 m od istočne kapije kastruma u pravcu jugoistoka. Daljim istraživanjima, na razdaljini od svega dvadesetak metara otkriven je i gravitacioni kanal drugog akvedukta koji je paralelan sa trasom prethodnog. Tokom 2003. godine vršena su intenzivna istraživanja akvedukta, te su oba iskopana u dužini od 1.150 metara. $^{1}$ Stanje ostataka je različito. Jednim delom su veoma dobro sačuvani kanali kojima nedostaje samo pokrivač. U drugom delu je očuvana temeljna zona. Na pojedinim delovima kanali se mogu pratiti samo u negativu. Otkrivanjem gravitacionih kanala postavilo se pitanje njihove trase, izvorišta, rezervoara i distributivnog sistema. Zbog ugroženosti celog prostora radom mehanizacije, kao imperativ nametnula su se istraživanja koja su išla u dva

1. Svi podaci navedeni u ovom članku preuzeti su iz terenske dokumentacije projekta Viminacium osim ukoliko nije drugačije naglašeno. 


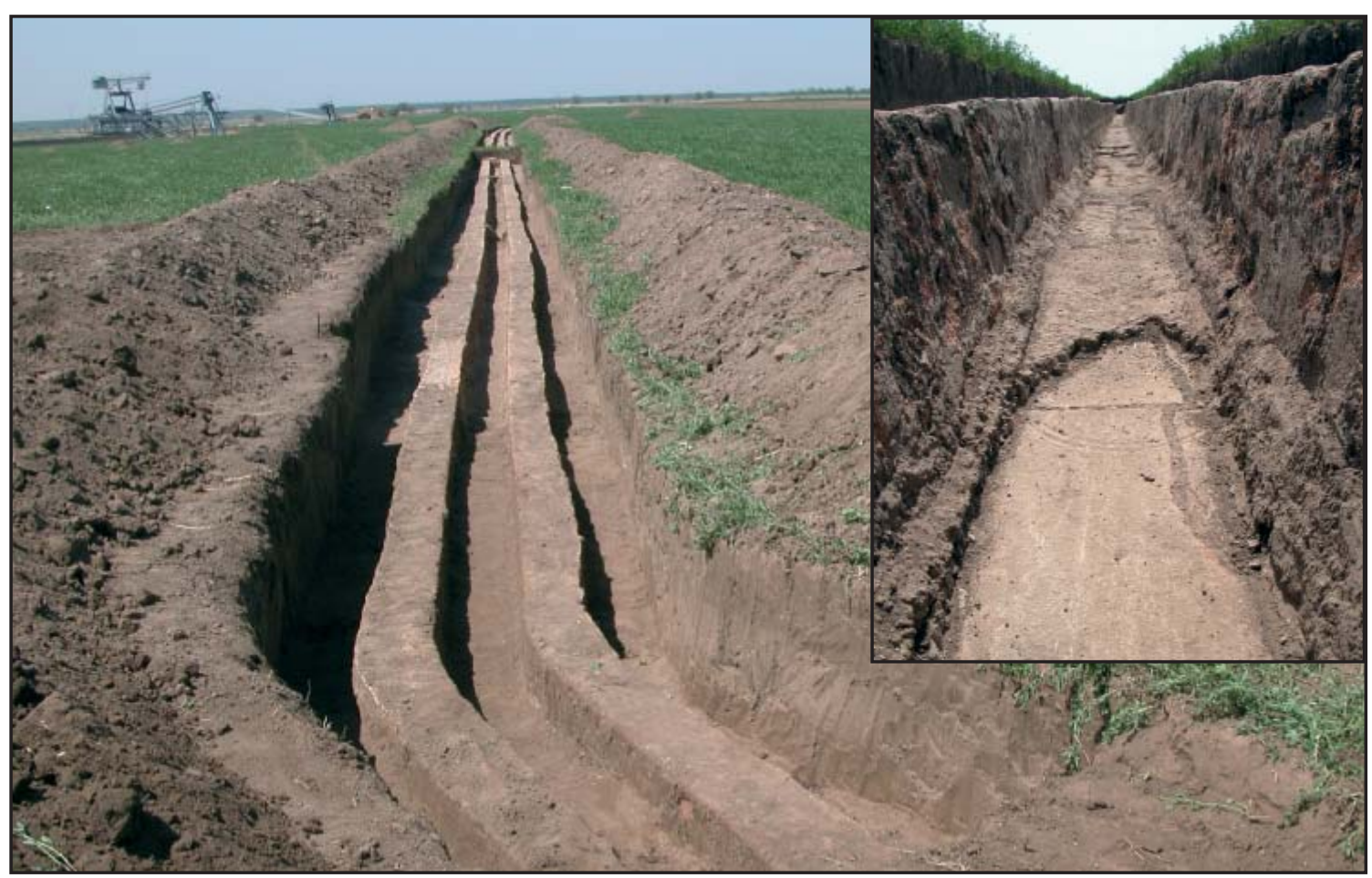

Slika 1. Rimski akvedukt otkriven na lokalitetu Stig - gravitacioni kanal sa detaljem unutrašnjosti (fotografija: M. Korać)

pravca: arheološko iskopavanje i kartiranje da bi se razumeo način vodosnabdevanja grada i mogao razraditi plan dalje zaštite. Obe vrste istraživanja bile su podržane geofizičkim snimanjima, pre svega pomoću georadara. Ona su imala za cilj, s jedne strane, da pruže informaciju o stanju podzemnih ostataka kako bi se mogle najpreciznije postaviti sonde, a sa druge da potvrde rezultate rekognosciranja terena.

Ranija istraživanja dala su prve indicije da je $u$ gradu postojao razgranat sistem vodosnabdevanja koji je pratila i razvijena kanalizaciona mreža. Olovne cevi bile su čest nalaz prilikom istraživanja grada i logora koja su vršili Mihailo Valtrović i Miloje Vasić. Tokom novijih istraživanja usmerenih ka zoni istočne nekropole nađeno je više fragmentovanih olovnih cevi. Istraživanje velikih gradskih termi takođe je doprinelo razumevanju vodovodno-kanalizacionog sistema unutar grada.

Značajan podatak o sistemu vodosnabdevanja pružio je Feliks Kanic koji je tokom druge polovine
XIX veka u više navrata posetio Viminacium. ${ }^{1}$ Prilikom opisivanja ostataka grada koje je video navodi da se „na istočnoj strani primećuje jedan odvojen deo, koji je verovatno opasan zidom, štitio grad sa istoka. ${ }^{2}$ Isto tako se jasno razaznaju temelji mnogih zgrada, ostaci vodovoda kojim je dovođena voda sa brda Lipovica udaljenog 15 milja i nekoliko cisterni za vodu“‘3. Iako ne navodi bližu lokaciju ni cisterni - rezervoara ni vodovoda, po redosledu opisa svog puta i nabrajanja stiče se utisak da se ovi objekti prostiru u nizu od kastruma prema istoku. Tokom vremena lokalno stanovništvo je intenzivno koristilo materijal sa akvedukta za gradnju kuća i drugih pratećih objekata po okolnim selima. Od onoga što je Kanic video danas se na površini zemlje ne može uočiti ništa. Tek su savremena istraživanja, od kojih su neka predmet ovog rada, potvrdila ova zapažanja Feliksa Kanica.

1. Prvi put posećuje Viminacijum u maju 1860. (1866), a drugi put u oktobru 1887. godine.

2. Najverovatnije misli na vojni logor (castrum) VII Klaudijeve legije (Legio VII Claudia Pia Fidelis).

3. Kanic, 1984. 179 
Pretpostavljalo se da je izvorište ovih akvedukatau obližnjimbrdima, odakle korišćenjem prirodnog pada terena voda dovođena do grada. Sila gravitacije je jedini pokretač vode u celom sistemu vodosnabdevanja Viminacijuma. Na taj način se izbegavaju složena tehnička rešenja potrebna za podizanje vode u okviru sistema napajanja na više kote. Već prilikom preliminarnih pregleda karata shvatilo se da je idealan put onaj koji je skoro i najduži. Kanali su morali da priđu gradu u velikom luku i bili su znatno duži ukoliko se u celosti želeo ispoštovati princip slobodnog pada. Prava linija, koja je najkraći put, zbog prepreka u konfiguraciji terena bila je odbačena.

Kartiranje je kao deo istraživanja izvedeno u sklopu međunarodnog projekta koji se realizuje sa Univerzitetom u Olbaniju (University of Albany, NY USA). Grupa američkih studenata učestvovala je u početnim fazama rekognosciranja. Uvodno kartiranje vršeno je zajednički u toku tronedeljnog boravka američkog dela ekipe, a nastavljeno je samostalno u narednim mesecima dok su trajali zaštitni radovi.

\section{METODOLOGIJA}

Kartiranje je vršeno u više faza, u periodu od proleća do kasne jeseni, u više etapa rekognosciranja istog terena i u različitim godišnjim dobima. Na taj način su se paralelno mogli pratiti tragovi u vegetaciji i rasprostiranje šuta kada vegetacije nije bilo - nakon oranja ili u kasnu jesen.

S obzirom da je akvedukt objekat od strateškog značaja u njegovoj neposrednoj blizini je bila zabranjena gradnja - najmanje 15 stopa sa svake strane van grada (extra urbem), a u gradu (intra urbem) na 5 stopa sa svake strane. Ova pravila su mogla biti i izmenjena te je moglo biti i po samo 8 stopa sa svake strane vodovoda (Ilakovac, 1982: 21-22). Kada je bilo moguće, udaljenost objekata ili drveća je bila i veća. U praksi se ovo pokazalo kao tačno. U zoni od oko $2 \mathrm{~km}$ ispred

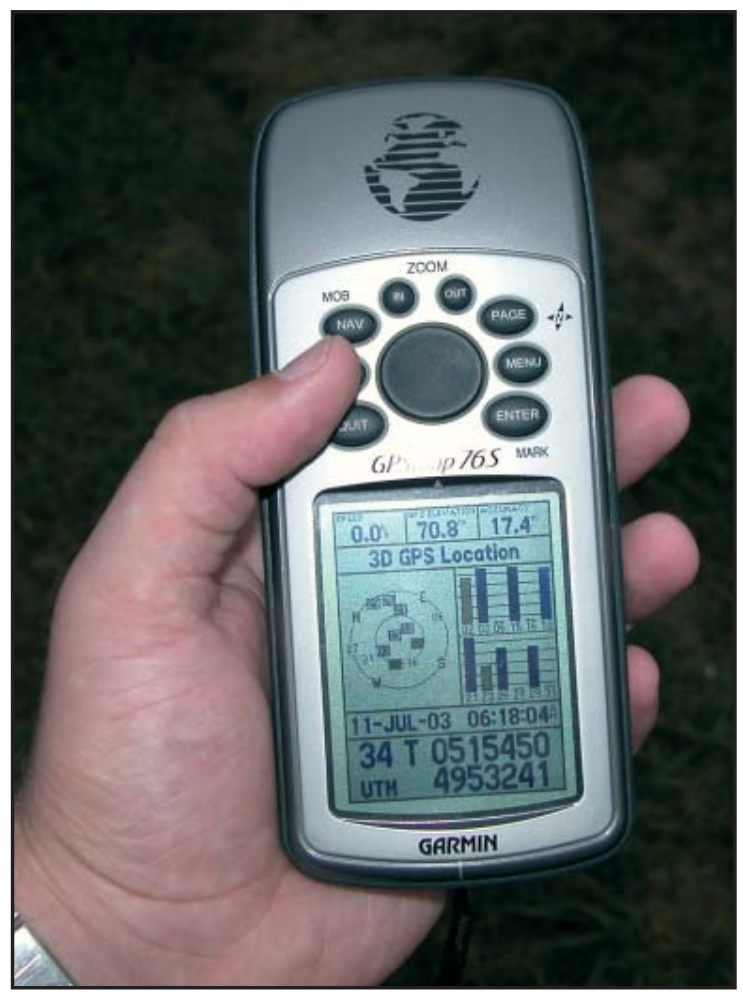

Slika 2. Garminov GPS MAP 76S

grada do one preko $5 \mathrm{~km}$ daleko od bedema jedini objekat koji je detektovan u blizi akvedukta je jedna najverovatnije, villa rustica udaljena oko 90-100 m od gravitacionih kanala ${ }^{4}$. Akvedukt se može uočiti pomoću šuta koji se linijski prostire duž njiva, kao i pomoću vegetacije koja se takođe menja linijski po (boji, gustini i visini). $\mathrm{Na}$ mestima gde su se tragovi gubili ili gde se sumnjalo na skretanja kanala, vršena su geofizička snimanja pomoću georadara (Ground Penetrating Radar - GPR) i zatim se u zavisnosti od rezultata nastavljalo sa rekognosciranjem 5 . Pored toga kao potvrda pravca poslužila su i mesta na kojima su linije cevi za odvođenje podzemnih voda ${ }^{6}$ presekle trasu akvedukta, te je on nađen u profilima kanala (sl. 4).

$\mathrm{Na}$ mestima na kojima je rekognosciranjem utvrđena trasa akvedukta, instrumentom za globalno pozicioniranje merene su tačke $u$

4. Redžić, Raičković 2006

5. Za detalje ovih istraživanja pogledati rad o geofizičkom snimanju akvedukata u ovom broju časopisa.

6. PLB (Peskovita Linija Bunara) i ŠLB (Šljunkovita Linija Bunara) 
središnjim delovima koncentracija materijala pronađenog na površini. Birana su ona mesta na kojima je pronađeno više komada opeke, kamena ili maltera (hidrostatičkog i krečnog). Opis svake pozicionirane tačke je unošen u formular koji je napravljen posebno za ovu priliku. Na mestima gde su uočene promene u vegetaciji takođe su merene tačke.

Kao početni deo rekognosciranja, određene su krajnje tačke poznatog dela akvedukta prema gradu, odnosno prema izvorištu (Prilog 1). Za potrebe ovog istraživanja preuzeta su ranija geodetska merenja dela trase od novog kličevačkog puta prema gradu koji je sada razrušen napredovanjem kopa. Kartiranje je izvršeno i na delu akvedukta koji je iskopan. Tačke su uzimane na svakih $5 \mathrm{~m}$ na pravcu kanala i na svaki metar na mestima skretanja da bi se ona što bolje naglasila (Prilog 2).

Problem su najviše predstavljale promene pravca akvedukta čija se mesta nisu mogla unapred pretpostaviti. Stoga je svako gubljenje traga odnosilo puno vremena da bi se rekognoscirale sve njive u okolini i konstatovao nastavak pravilnog rasprostiranja šuta i drugih tragova.

Softver koji je korišćen za primarnu obradu podataka je GPS Utility 4.10.2. U daljem radu korišćen je Trimble Geomatics Office, a testiran je i niz drugih GIS programa. Sve tačke su prenete na prethodno georeferencirane digitalizovane topografske karte (1:2500 i 1:10000) i kasnije na više aerosnimaka, snimljenih različitih godina i pod različitim uslovima. Za georeferenciranje karata korišćene su geodetske tačke iz nacionalne geodetske mreže kao jedini pouzdani reperi (najmanje četiri tačke na svakoj karti). Za georeferenciranje aerosnimaka korišćene su karakteristične tačke raskrsnica i uglovi objekata koji su bili vidljivi na snimku. Na taj način je preko niza tačaka stvoren lokalni geodetski sistem

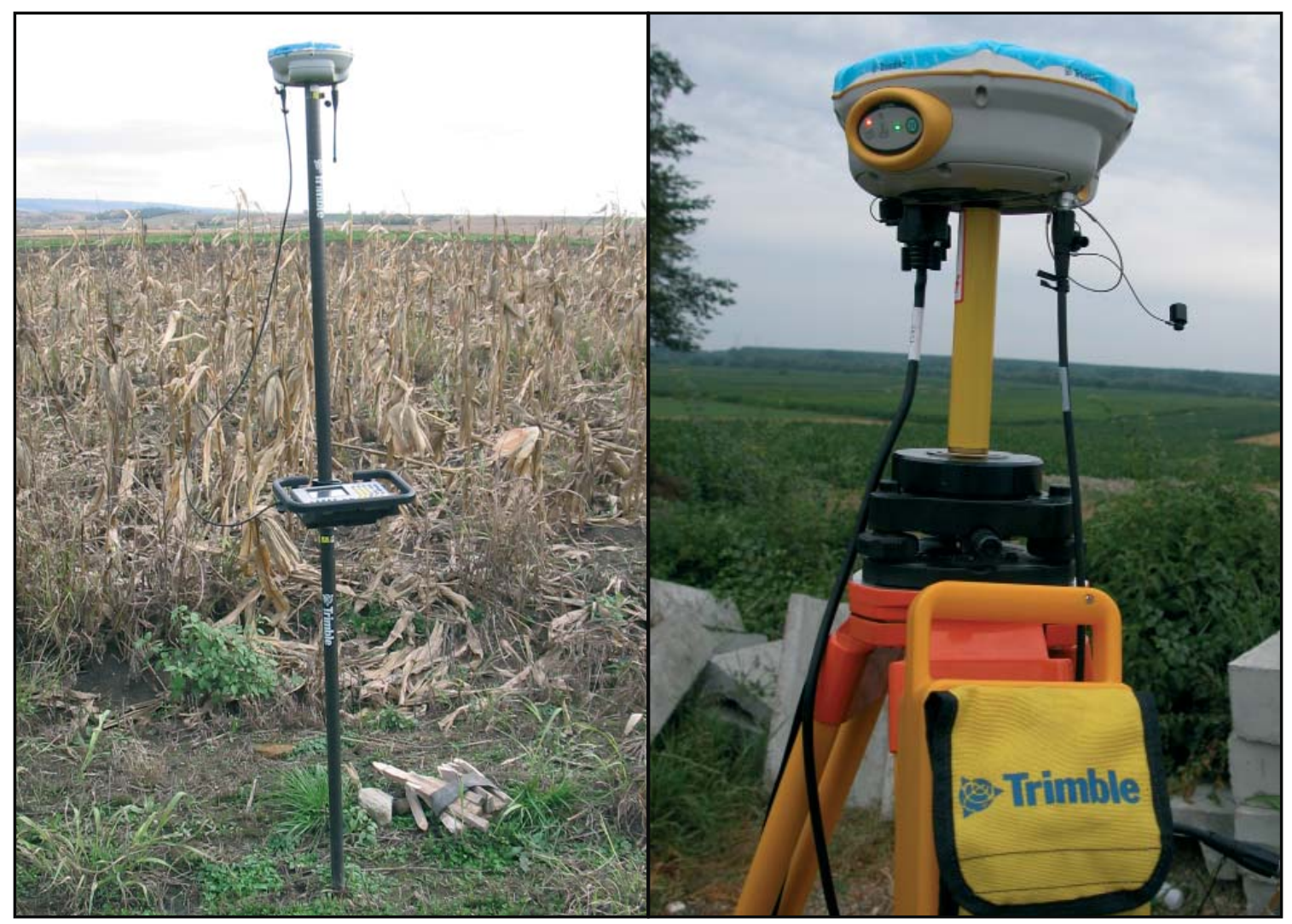

Slika 3. Trimble GPS 5800 Totalna stanica: GPS rover (levo) i bazna stanica za korekciju lokacije putem radio signala (desno) (foto: N. Mrđić). 
u okviru koga su učitavani podaci sa GPS-a. Kartiranje je sistematski vršeno u timovima od 35 ljudi sa jednim (Trimble 5800) ili dva (Garmin GPS MAP 76S) GPS uređaja.

U prvoj fazi kartiranja korišćen je Garminov model GPS MAP 76S (sl. 2). Srednja preciznost uređaja je prema fabričkim standardima 3-5 $\mathrm{m}$, mada se $\mathrm{u}$ terenskim uslovima pokazalo da može biti i veća - do 2,2 m. Preciznost uređaja je izražena u radijusu u kome je sa $90 \%$ garantovana koordinata. Ravan teren i oskudna vegetacija omogućila je maksimalan prijem satelistkog signala a samim tim i maksimalnu preciznost instrumenta. Da bi se povećala preciznost, korišćene su prosečne vrednosti čitanja na terenu. Merenje tačaka vršeno je u trajanju od najmanje jednog minuta, što je unapred postavljeno kao norma. Takav način merenja je obezbedio veću preciznost i umanjio mogućnost grešaka.

U drugoj fazi korišćen je Trimblov GPS subsantimetarske tačnosti da bi se uradila korektura tačaka koje su prethodno snimljene. Pošto je samo ograničen broj tačaka mogao tokom istraživanja da bude ponovo izmeren one su bile od izuzetne važnosti za utvrđivanje preciznosti celokupnog rekognosciranja sa Garminovim modelom. Prilikom rada u drugoj fazi, korišćena su dva Trimble GPS 5800 prijemnika u sprezi (sl. 3). Jedan je korišćen kao bazna stanica kojim je vršena korektura satelitskog signala sa fiksne geodetske tačke i za komunikaciju sa pokretnim prijemnikom. Komunimacija je vršena putem radio veze radi korekcije merenja i postizanja veće tačnosti izmerenih vrednosti. Pokretni GPS prijemnik (rover), meri date pozicije na terenu uz pomoć emisije satelitskog signala i emisije radio signala bazne stanice. Time je preciznost povećana, a mogućnost greške spuštena na ispod $20 \mathrm{~mm}$. Mane Trimblovog modela, kada govorimo o njegovom korišćenju za potrebe

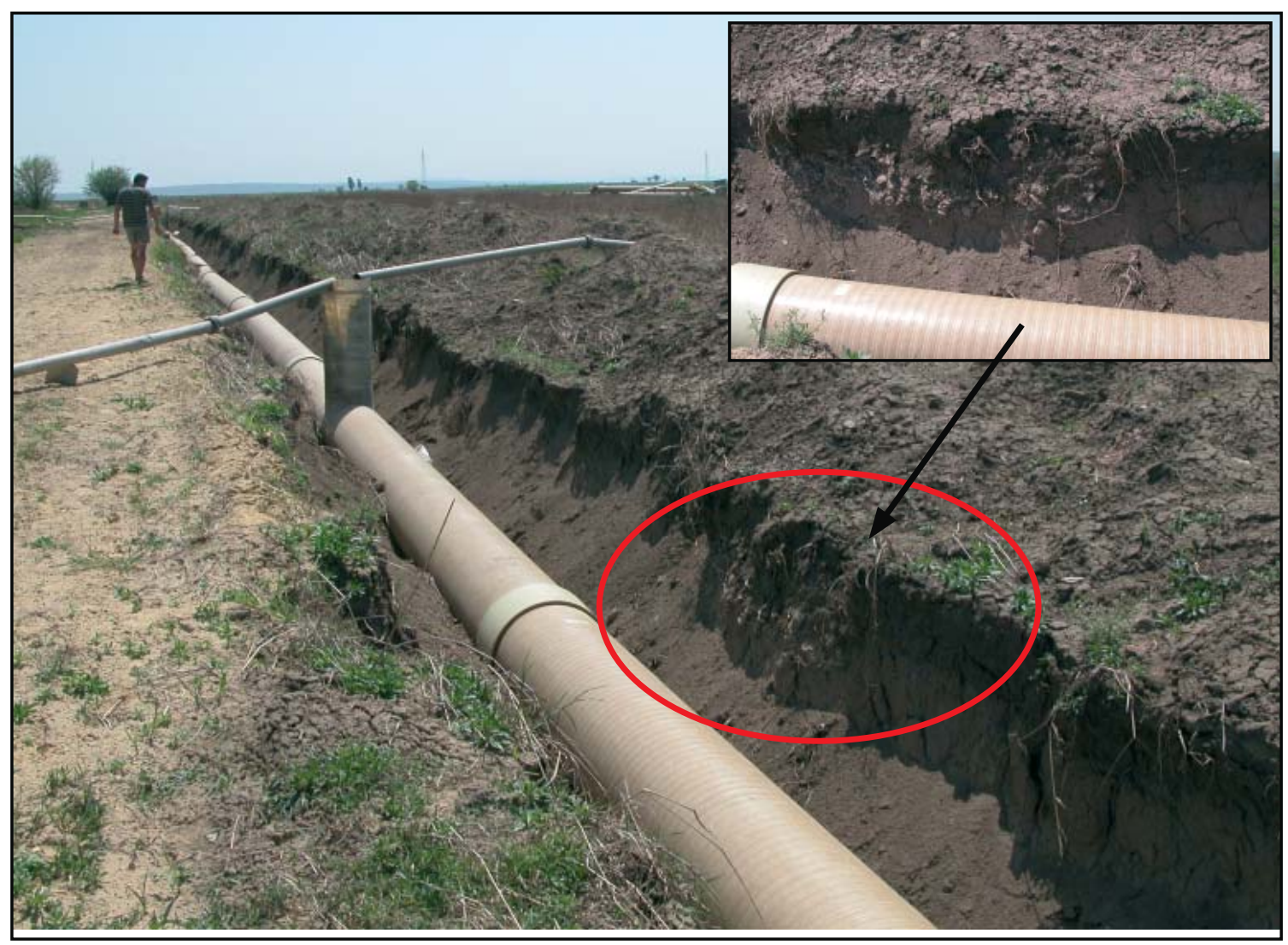

Slika 4. Ostaci temeljne zone akvedukta u profilu kanala cevovoda (fotografija: M. Korać) 
rekognosciranja, su izuzetno visoka cena i veličina prijemnika. Garminov model je daleko manji i veličine je mobilnog telefona. S druge strane preciznost modela Trimble 5800 je dvadeset puta veća.

U metodološkom smislu potrebno je naglasiti još jednu bitnu stvar kod korišćenja ovako sofisticirane opreme za potrebe arheološkog rekognosciranja. Trimble 5800 je neosporno nezamenjiv tokom arheoloških iskopavanja, gde se kotiraju pokretni ili nepokretni nalazi, sa milimetarskom preciznošću. Garmin se tokom rekognosciranja pokazao kao sasvim solidno rešenje sa većom autonomijom rada ${ }^{1}$ i neograničenim radijusom kretanja. Preciznost Trimble 5800 GPS-a u velikoj meri zavisi od signala bazne stanice, čiji je radijus ograničen, a bez kojeg preciznost drastično pada na čak oko $2 \mathrm{~m}$ što je nešto više od Garminovih najboljih rezultata. Prilikom rekognosciranja u velikoj meri su kotirani razvučeni šut ili konstrukcije koje su se nalazile ispod zemlje, a uočeni su na razne načine. U takvim slučajevima razlike u preciznosti su se pokazale kao nebitne. Lokacija tako konstatovanog objekta je realno mogla varirati 1-2 m što je i predviđena greška Garminovog GPS uređaja bez korekcije satelitskog signala. Za regionalni tip rekognosciranja i kartiranja preciznost kao takva je sasvim zadovoljavajuća.

$\mathrm{Na}$ osnovu toga, želja autora ovog rada je da naglasi važnost korišćenja ovih uređaja prilikom terenskih istraživanja, a čija je cena dostupna arheološkim institucijama.

\section{REZULTATI}

Rekognosciranje, iako nekontinuirano, trajalo je više meseci. Na terenu je provedeno oko 30 radnih dana. Skoro isto toliko je trajala i obrada prikupljenih podataka, formiranje GIS baze podataka i konačna interpretacija.

1. Manja potrošnja baterija i jednostavna izmena - koristi 4 obične alkalne AA baterije $1,5 \mathrm{~V}$
Trasa ka izvorištu predstavljala je daleko veći izazov. Caput aquae sa kaptažnim izvorima bio je jedan od važnih ciljeva ovog rekognosciranja. $\mathrm{Na}$ žalost, istraživanja u ovom pravcu nisu bila tako uspešna. Ova zona nije ugrožena radovima kopa, tako da nije bilo mogućnosti da se rezultati provere. Zbog visoke i guste biljne kulture neomogućena su dalja geofizička istraživanja kao i rekognosciranje. Stoga se sve što se o ovom sektoru može reći mora uzeti sa dozom rezerve. Pravac je vodio ka jugozapadu pored veštačkog brda - deponije zemlje, kod Galovca. Trag je konačno izgubljen na oko $3 \mathrm{~km}$ od novog kličevačkog puta koji preseca akvedukt. Poslednji siguran pravac je bio ka selu Majurevac. Do najbližih brda preostalo je još najmanje $3-4 \mathrm{~km}$. Usled obimnih radova na istraživanju i izmeštanju ugroženog dela akvedukta, rekognosciranje ovih brda je moralo biti odloženo. Lokacija kaptaža ostala je nepoznata. Buduća istraživanja biće usmerena u tom pravcu.

Tokom rekognosciranja u pravcu grada nije bilo većih problema sa praćenjem akvedukta. Početna pretpostavka da će akvedukt proći duž južnog bedema i otići pravo u grad brzo je odbačena jer praćena trasa vodi suviše prema severu. Takođe, za naglu promenu pravca nema osnova zbog izdužene duboke depresije pozajmišta gline koje se nalazi na putu, a pruža se u pravcu sever-jug u dužini od oko $700 \mathrm{~m}$ (lokalitet Svetinja - prilog 4). S druge strane blagi pad terena od otkrivene trase je ka severoistoku, zatim se skreće ka zapadu - upravo onako kako su tragovi arhitekture i praćeni. Severno od lokaliteta Pirivoj (istočna nekropola Viminacijuma) teren počinje naglo da pada u pravcu severa. ${ }^{2}$ Ukoliko bi se akvedukt spustio niz ovu padinu više ne bi postojala mogućnost da se jednostavnim rešenjem vrati na nadmorsku visinu grada. Prostor od depresije do naglog pada terena je širine $300 \mathrm{~m}$ i predstavlja najuže mesto kojim su akvedukti morali da prođu ukoliko se želeo ispratiti princip 2. U pitanju je rečna dolina Dunava sa kaskadama starih rečnih korita koja su bila aktuelna u ranijim praistorijskim periodima. Visinske razlike se kreću i do $15 \mathrm{~m}$. 
slobodnog pada. Međutim, upravo u toj zoni, na oko $1200 \mathrm{~m}$ od istočnog bedema kastruma, on je i definitivno izgubljen jer je materijal počeo da se meša sa šutom od rasturenih grobova istočne nekropole i suburbanih objekata. Njive su u potpunosti prekrivene šutom i nije bilo govora o nekom linijskom praćenju šuta. Trasa, bar kako to izgleda na aerosnimcima, vodi ka severu do same ivice prirodne terase i tu naglo skreće ka zapadu u pravcu grada i logora. Dodatna potvrda ovog zaključka usledila je nakon obimnih zemljanih radova za potrebe savremenog cevovoda. Preko lokaliteta Pirivoj prolazi linija cevi koja odvlači vodu iz bunara za sabiranje podzemnih voda. Linije bunara sa pratećim cevovodom imaju za cilj da spreče plavljenje površinskog kopa podzemnim vodama. Jedna ovih linija bunara nalazi se u blizini kastruma. Približno je paralelna sa delom istočnog bedema. Kanal za ovu liniju cevi nije nigde presekao akvedukt. Arheološka istraživanja pratila su iskopavanje kanala celom dužinom. Konstatovan je veći broj grobova, nekoliko zidova manjih građevina, ali ne i tragovi gravitacionih kanala ili cevi. Prostor severno od zone iskopavanja je geofizički istražen uz upotrebu georadara (RAMAC GPR - Ground Penetrating Radar). Ova istraživanja su razrešila mnoge nedoumice o trasi akvedukta. Na žalost, na ovom prostoru je akvedukt verovatno uništen ili je očuvan samo u temeljnim zonama. Praćenje kroz zonu nekropole u oblasti devastiranoj redovnim oranjem bez sistematskog iskopavanja nije dalje bilo moguće.

Zone koje nisu mogle biti snimljene ili nisu mogle biti rekognoscirane iz drugih razloga analizirane su daljinskom detekcijom preko aerosnimaka. Na aerofotografiji snimljenoj 1996. godine jasno se uočavaju dve beličaste linije preko kojih su se sa dosta poklapanja našle tačke uzete na terenu. One se mestimično prekidaju, ali se mogu pratiti skoro do ispred samog kastruma. Tada je primenjeno takozvano "obrnuto kartiranje": na aerosnimku su uzete koordinate tačaka koje bi se mogle naći na trasi akvedukta i navođenjem preko
GPS-a je proveravana situacija na terenu. Ovo je dalo pozitivne rezultate u više od dve trećine slučajeva (u prilogu 1. označeno crvenom bojom). Na osnovu trasa uzetih tačaka može se zaključiti da je akvedukt vodio do kastruma u blizini severne polovine istočnog bedema, najverovatnije u zoni istočne kapije ${ }^{3}$. Prema Kanicovim opisima u ovoj zoni bi trebalo očekivati i velike rezervoare za vodu - što bi mogao biti glavni akumulacioni rezervoar i krajnja tačka akvedukta (castellum aquae). Na terenu se uočava velika depresija nedaleko od istočnog bedema. Moguće je da se radi o delimično ukopanom rezervoaru. Dimenzije ove depresije su veoma velike (100 x $50 \mathrm{~m}$, dubine do $2 \mathrm{~m}$ ?). Ako je u pitanju rezervoar, najverovatnije je ispunjen zemljom, dok je nadzemni deo konstrukcije u potpunosti razrušen. Po površini se jasno uočava šut u vidu kamena i maltera. Jedan od arheološki potencijalnih objekata uočenih na aerosnimcima podseća na oblik peščanog sata. Na terenu se ovaj objekat poklapa sa pomenutom depresijom. Takav oblik upravo ima istraženi castellum aquae iskopan na Medijani (Jeremić, 1988). Ova analogija ostaje da bude potvrđena daljim istraživanjima.

Trasa akvedukta je ispraćena $3 \mathrm{~km}$ južno od novog kličevačkog puta. Toliko je približno poznato i severno od kličevačkog puta na putu do grada. Do najbližeg brda gde bi mogli biti izvori ima najmanje još $4 \mathrm{~km}$, tako da je dužina akvedukata prelazila 10 kilometara. U toku rada memorisano je preko 650 tačaka, ne računajući one koje nisu direktno bile vezane za ovo tematsko rekognosciranje (prilozi 2, 3 i 4).

Jasno je potvrđeno da su gravitacioni kanali u potpunosti pratili konfiguraciju terena kako bi bez mehaničkih rešenja, samo slobodnim padom, sproveli vodu do grada. Krivine su pravljene na skoro pravilnim rastojanjima kako bi usporili i kontrolisali kretanje vodenog toka. Kako nam na osnovu rekognosciranja izgleda, najverovatnije su skretanja pravljena na razdaljinama od približno

3. Istočna kapija kastruma locirana je na $2 / 3$ dužine istočnog bedema u pravcu severa 
300 rimskih koraka ili 1500 stopa (između 440$450 \mathrm{~m}$ ). U zoni gde je bilo potrebno usporiti pad vode na veće razdaljine, kanali su vodili skoro po samim izohipsama (Prilog 4) prateći konturu terena, a nagib je veštački regulisan unutar samog kanala.

Oba akvedukta se prate skoro paralelno celom dužinom. Međusobno rastojanje varira kako bi se najdoslednije mogao ispratiti pad terena. Približavaju se najviše do $7 \mathrm{~m}$, a najveće konstatovano rastojanje je oko $40 \mathrm{~m}$. Interesantno je primetiti da se na delu rastojanja prati i treća linija šuta, arheološkim iskopavanjem i potvrđena u dužini od $15 \mathrm{~m}$. Radi se najverovatnije o trećem kanalu, koji je u iskopanom delu očuvan samo u temeljnoj zoni. Ova treća linija paralelna je sa prethodne dve trase. Da li je reč o trećem akveduktu, sekundarnom kanalu nekog od postojećih akvedukata ili kanalu za neke druge potrebe rešiće neki od budućih istraživačkih poduhvata.

\section{ZAKLJUČNA RAZMATRANJA}

Vodosnabdevanje $\mathrm{u}$ antici je od neizmernog značaja za razumevanje funkcionisanja gradskog načina života. Podizanje skupih vodovodnih sistema, dugačkih po više desetina kilometara, od jednostavnih do onih tehnološki složenih jasno ukazuje na važnost onoga što je nama obična svakodnevnica. Pomeni u izvorima su retki, ali nedvosmisleno veličaju ova građevinska dela. Frontin, Vitruvije i Plinije veliku pažnju posvećuju akveduktima.

Poredeći naša istraživanja sa obimnim radovima koji su sprovedeni u Španiji, južnoj Francuskoj, severnoj Africi i Bliskom istoku, a u našoj blizini u Dalmaciji (Ilakovac, 1978, 1982) i Makedoniji, uočava se koliko je kod nas malo pažnje posvećeno ovim objektima. Sirmium, Singidunum, Naissus, Mediana i Iustiniana Prima imaju jasno potvrđene ostatke vodovoda, dok su na nizu antičkih lokaliteta samo otkriveni pojedinačni tragovi cevi ili rasturenih kanala (Taliata, Municipium S, Margum, Horreum Margi, Felix Romuliana, Aquae). Veliki gradovi prema tome nisu bili usamljeni primeri jedne civilizacijske tekovine, već se ona prati širom provincije. Na žalost, sistematskim istraživanjima ovih objekata bavilo se malo istraživača kao što su Petar Milošević, Petar Petrović, Miroslav Jeremić i Toni Čerškov.

Ublizini Požarevca su već ranije otkriveni tragovi rimskih akvedukata. ${ }^{1}$ Prvi rezultati su objavljeni, ali istraživanja nisu vršena dalje u tom pravcu. Iako ovaj vodovod nije deo sistema za snabdevanje Viminacijuma, dobar je primer razgranate mreže akvedukata šire gradske zone. Očigledno je da sveža voda nije bila privilegija samo jednog urbanog centra na ovom prostoru.

Ovaj rad ima za cilj da pre svega pruži jedan metodološki drugačiji pristup interdisciplinarnim istraživanjima. Geofizička istraživanja, daljinska detekcija, arheološka iskopavanja i rekognosciranje dopunjavajući se satelitskom navigacijom dali su izuzetno dobre rezultate. Kartiranje ovog megaobjekta postavilo je šablon po kome se danas radi na kartiranju i interpretaciji objekata iz uže i šire gradske okoline. Time je omogućeno upoznavanje prostora koji je najdirektnije vezan iusmeren na grad i posredno utiče na život metropole. Metodologija je sa nešto modifikacija primenjena na istraživanje i kartiranje samog najužeg urbanog jezgra - grada i legijskog logora unutar odbrambenih bedema (intra muros).

U ovom trenutku akvedukti su i dalje ugroženi radovima na prostoru ispred površinskog kopa „Drmno“. Deo koji je najbolje očuvan izmešten je na bezbednu lokaciju koja se poklapa sa originalnom trasom akvedukta. Poznavanje njihove trase omogućiće adekvatno planiranje daljih istraživanja i zaštite. Preliminarni rezultati iskopavanja su objavljeni, ${ }^{2}$ dok je u pripremi monografija koja se detaljno bavi vodosnabdevanjem metropole Gornje Mezije.

1. Спасић, Јацановић, 1997

2. Blagojević i Pavelka, 2004 


\section{RESUME}

Mapping of the Roman Aqueduct Using Global Positioning System

In spring of 2003 digging activities of the surface coal mine Drmno, on site Stig revealed walls of the channel belonging to the roman aqueduct. Protective excavations that were undertaken found another aqueduct on very short distance.

In order to explore water supply system of roman Viminacium systematic multidisciplinary survey and mapping were done. Aqueducts were mapped 6 kilometers in length using GPS (Global Positioning System). Only 1150 meters of water channels were excavated. The rest of water supply system is archaeologically surveyed. Parts that were uncertain were additionally surveyed with Ground Penetrating Radar (GPR) and different methods of remote sensing. On maps we presented routs of channels and place of main reservoirs.

We aim to present new approach to research of macro archaeological structures using different methods and strategy.

Translated by Nemanja Mrđić

\section{BIBLIOGRAFIJA}

\section{Blagojević, Stojković-Pavelka 2004}

Blagojević, M. i Stojković-Pavelka, B. 2004. Viminacium - lokalitet „Stig“ - Akvedukt. Glasnik društva konzervatora Srbije 28: 62-64. Beograd: Zavod za zaštitu spomenika kulture.

\section{Dautova-Ruševljanin 1989}

Dautova-Ruševljanin, V. 1989. Sremska Mitrovica Sirmium - akvedukt. Arheološli pregled 28: 112. Ljubljana: Savez Arheoloških društava Jugoslavije.

\section{Ilakovac 1978}

Ilakovac, B. 1978. Razvoj ceste Stara Straža - Radučić u odnosu na trasu akve-dukta Plavno polje - Burnum. Putevi i Komunikacije u Antici (Materijali XVII): 109-123. Peć: Savez arheoloških društava Jugoslavije i Muzej Kosova - Priština.

\section{Ilakovac 1982}

Ilakovac, B. 1982. Rimski akvedukti na području Sjeverne Dalmacije. Zagreb: Arheološki muzej Zadar i Sveučilišna naklada Liber.

\section{Jeremić 1988}

Jeremić, M. 1988. Castellum aquae antičke Medijane. Starinar XXXIX: 61-81. Beograd: Arheološki institut.

\section{Kanic 1985}

Kanic, F. 1985. Srbija zemlja i stanovništvo od rimskog doba do kraja XIX veka. Beograd: Srpska književna zadruga.

\section{Катанић, Гојковић 1961}

Катанић, Н. и Гојковић, М. 1961. Грађа за проучавање старих камених мостова и акведуката y Србији, Македонији и Црној Гори. Београд: Савезни институт за заштиту споменика културе.

\section{Katanić, Gojković 1972}

Katanić, N. i Gojković, M. 1972. Građa za proučavanje starih kamenih mostova $i$ akvedukata $u$ Hrvatskoj. Beograd - Zagreb: Jugoslovenski institut za zaštitu spomenika kulture i Republički zavod za zaštitu spomenika kulture SR Hrvatske.

\section{Vitruvije, De architectura}

Marko Vitruvije Polio. 1952. De architectura - O arhitekturi. Sarajevo: Veselin Masleša.

\section{Milošević 1969}

Milošević, P. 1969. Sremska Mitrovica (Sirmium) - Banoštor (Bononia) - rimske komunikacije i vodovodi: Arheološki pregled 11: 199-201. Beograd: Arheološko društvo Jugoslavije. 


\section{Milošević 1971}

Milošević, P. 1971. Earlier Archaeological activity in Sirmium: Sirmium II: 3-11. Beograd: Arheološki institut.

\section{Milošević 1971a}

Milošević, P. 1971. Raniji nalazi u Sirmijumu: Sirmium II: 13-14. Beograd: Arheološki institut.

\section{Petrović 1970}

Petrović, N. 1970. O vodovodu Caričinog grada. Starinar XX: 289-297. Beograd: Arheološki institut.

\section{Petrović 1979}

Petrović, P. 1979. Inscriptions de la Mesie Superieure Vol. IV - Naissus - Remesiana - Horreum Margi. Beograd: Centre d'etudes Epigraphiques et Numismatiques de la Faculte de Philosophie Beograd.

\section{Redžić, Raičković, Miletić 2006.}

Redžić, S. i Raičković, A. 2006. Primena georadara na lokalitetu „Stig“ - objekat sa apsidom. Arheologija i prirodne nauke I: 47-55.

\section{Renfrew, Bahn 2000}

Renfrew, C - Bahn, P., 2000: Archaeology, Theories Methods and Practice, 3rd ed., London 2000, 71-116.

\section{Спасић, Јацановић 1997.}

Спасић, Д. Јацановић, Д. 1997. Римски водовод на “Тулби” у Пожаревцу. Гласник САД 13: 159-163

\section{Vinčik, Ivanovski 1990.}

Vinčik, Ž. Ivanovski, M. 1990. Stobi - akvedukt. Kulturno nasleđe 14-15:63-73.

\section{Petrović 1999.}

Petrović, P. 1999. Niš u antičko doba. Niš: Prosveta.

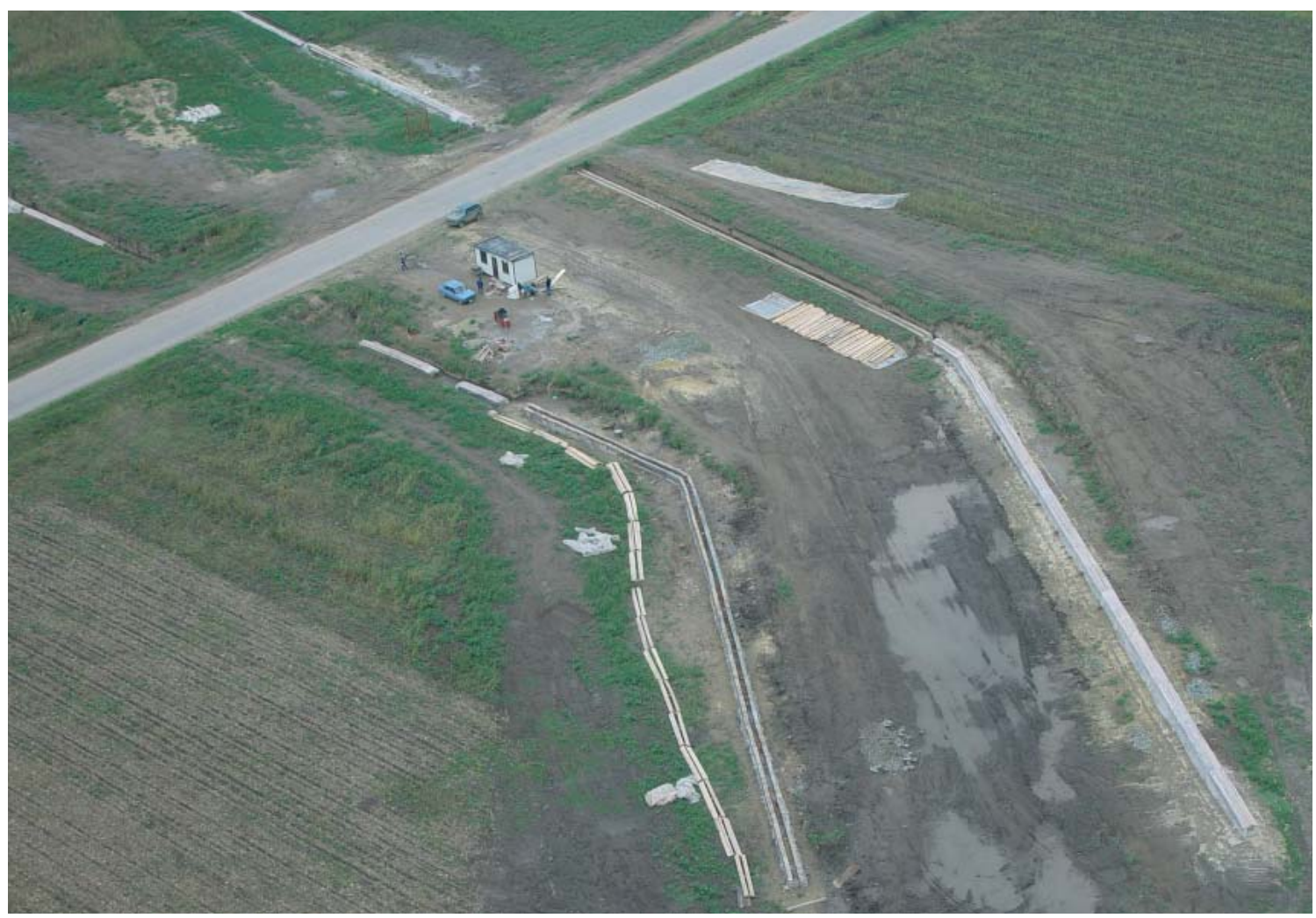

Slika 5. Pogled iz vazduha na akvedukte tokom iskopavanja (foto M. Korać) 


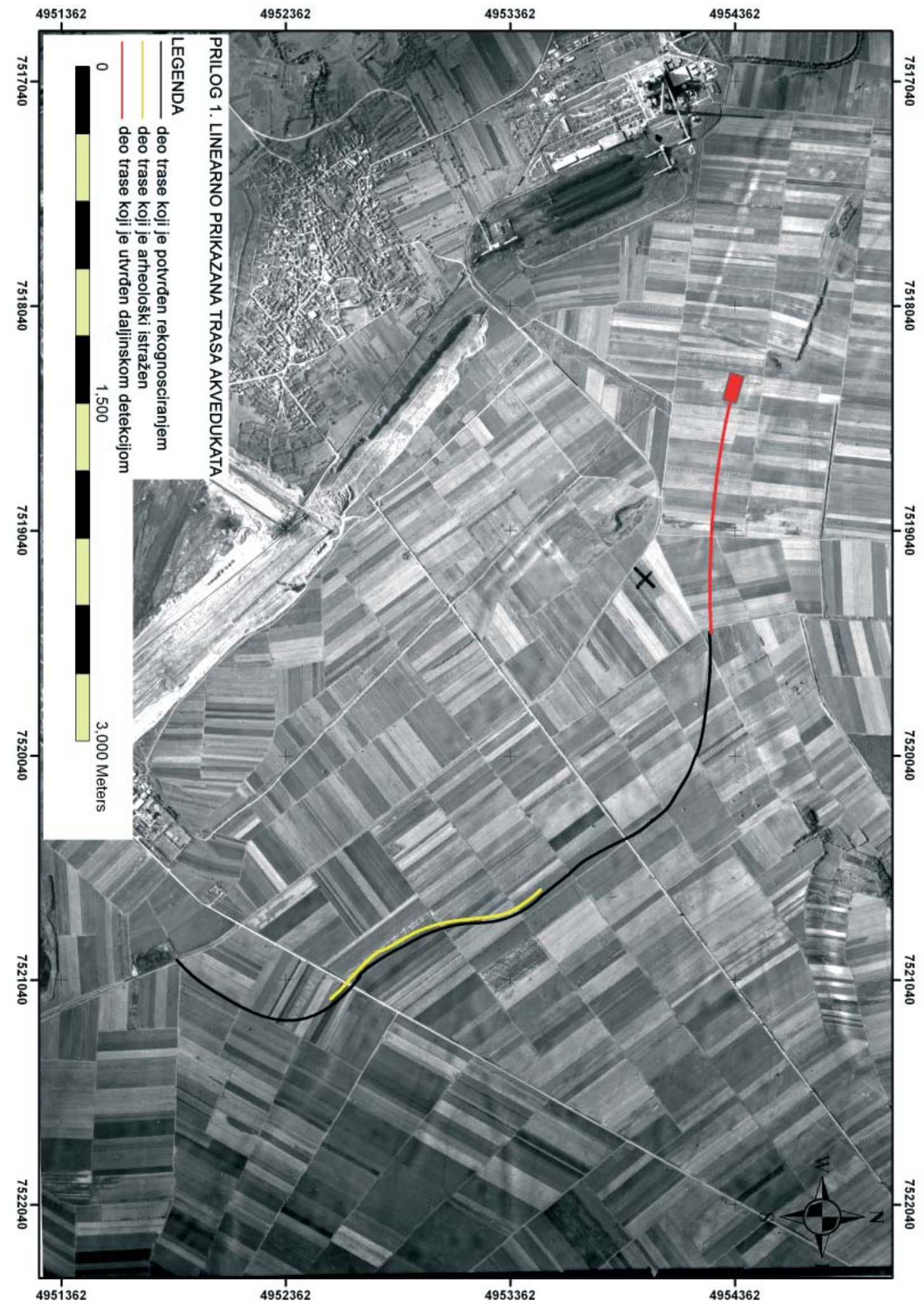




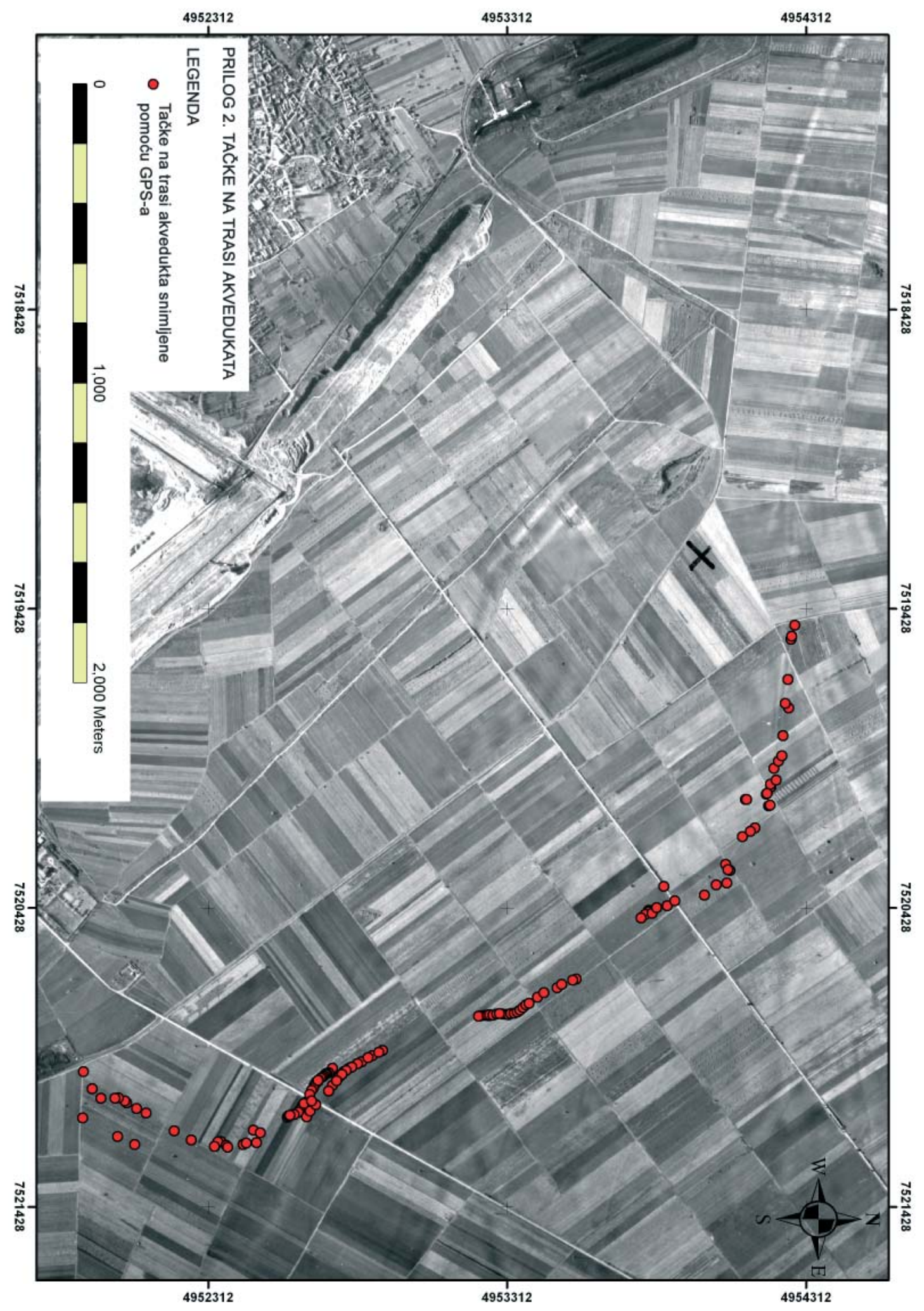




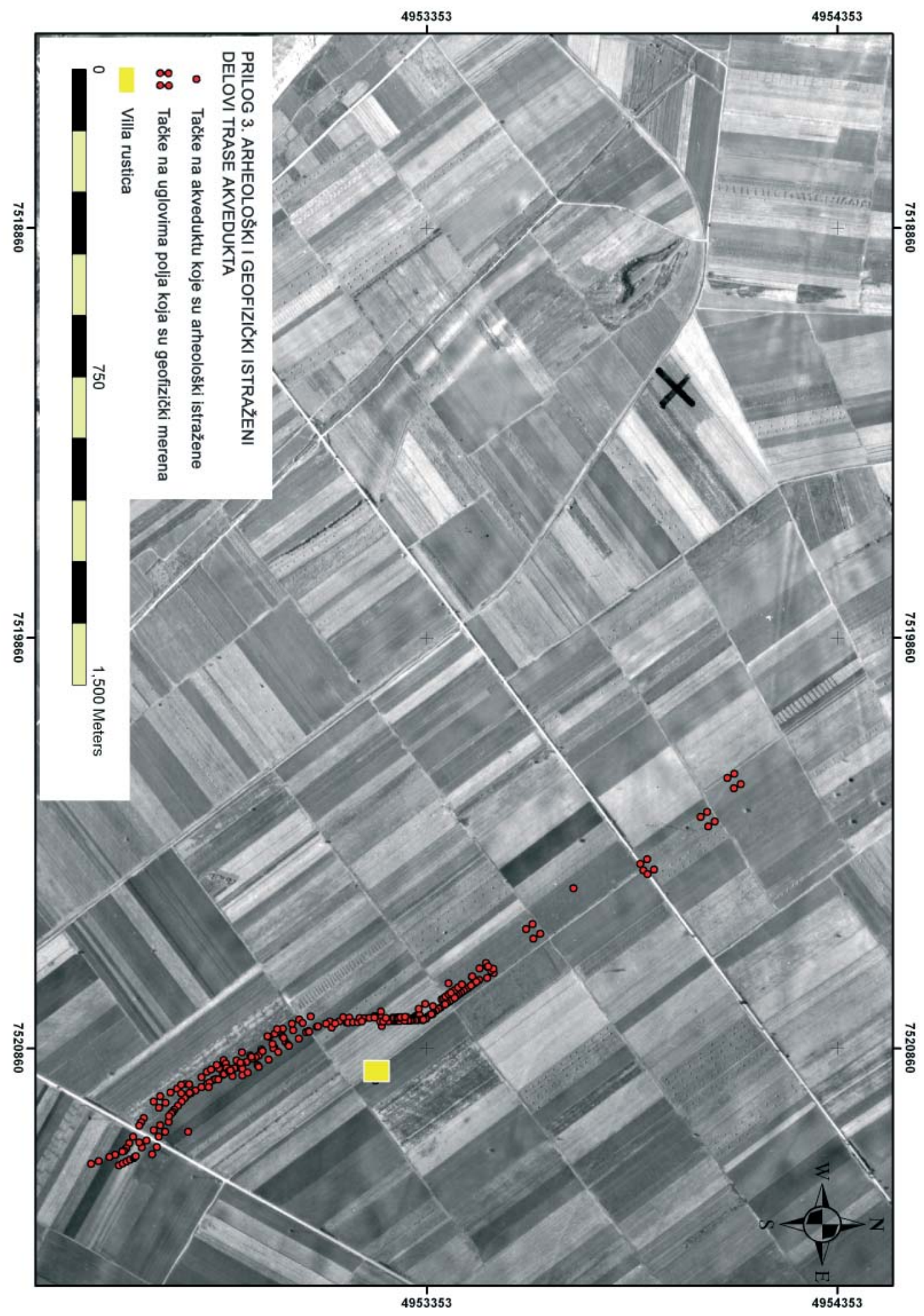




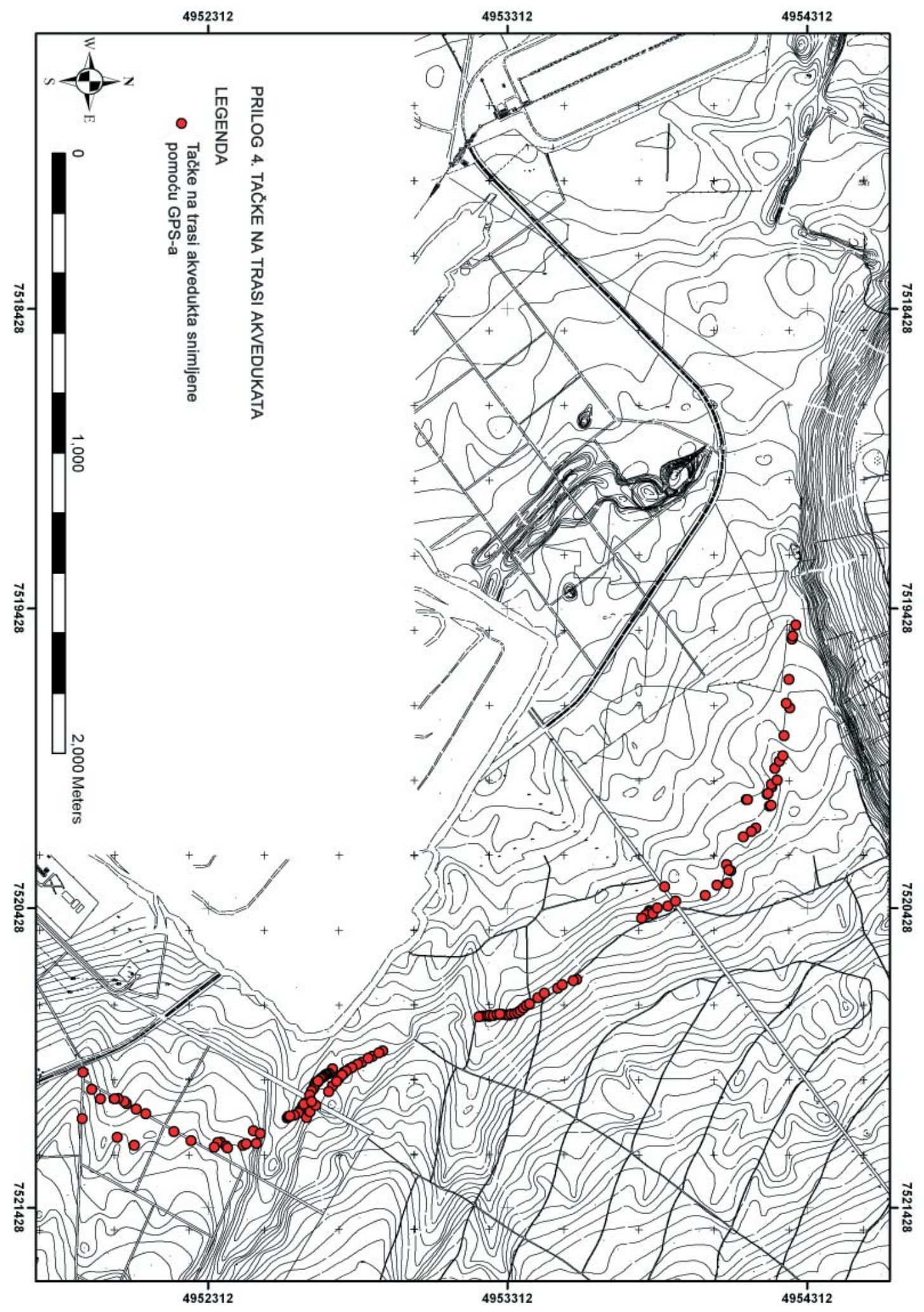

